\title{
Low nitrogen and phosphorus release from sediment deposited on a Danish restored floodplain
}

\author{
Joachim Audet $^{1 *}$, Carl C. Hoffmann ${ }^{1}$ and Henning S. Jensen ${ }^{2}$ \\ 1 Department of Bioscience, Aarhus University, Vejlsøvej 25, DK-8600 Silkeborg, Denmark \\ 2 Institute of Biology, University of Southern Denmark, Campusvej 55, DK-5230 Odense M, Denmark
}

Received 26 October 2010; Accepted 13 April 2011

\begin{abstract}
River floodplains and riparian areas are often considered efficient traps for sediment and sediment-associated nutrients such as nitrogen $(\mathrm{N})$ and phosphorus $(\mathrm{P})$. However, few studies have focused on the fate of sediment-bound $\mathrm{N}$ and $\mathrm{P}$ after deposition on floodplains. In this study, the leaching of $\mathrm{N}$ and $\mathrm{P}$ from sediment deposited on a Danish-restored floodplain was quantified by placing trapped sediment samples under a rainfall simulator and exposing them to in situ temperatures and precipitation for two months. The nitrate release was $2.72-1600 \mu \mathrm{g} \mathrm{NO} \mathrm{NO}_{3}-\mathrm{N}_{\text {g }}{ }^{-1} \mathrm{DW}$ which corresponded to $0.06-6.42 \%$ of the total nitrogen contained in the sediment. Total dissolved phosphorus (TDP) release was $0.44-3.17 \mu \mathrm{g} \mathrm{P.g}{ }^{-1} \mathrm{DW}$, corresponding to $0.021-0.065 \%$ of the TP content of the sediment. Our results indicate that $\mathrm{N}$ and $\mathrm{P}$ release from floodplain sediment subjected to rainfall events is very low, which should be considered when applying floodplain restoration to mitigate the load of $\mathrm{N}$ and $\mathrm{P}$ to rivers.
\end{abstract}

Key words: Phosphorus / nitrogen / floodplain / river / restoration

\section{Introduction}

River floodplains are, in their natural state, an ecotone between aquatic and terrestrial ecosystems (Naiman and Decamps, 1997). Natural floodplains are uniquely positioned in the landscape, they exhibit important riverrelated hydrological and geomorphic processes and are recognized as valuable ecosystems with high biodiversity (Junk et al., 1989; Naiman and Decamps, 1997; Ward et al., 1999; Tockner et al., 2000). Furthermore, floodplains are important zones for sediment deposition and exchange or transformation of nutrients in connection with the river (Naiman and Decamps, 1997; Tockner et al., 1999; Pinay et al., 2000, 2007).

However, human activities have greatly altered the valuable functionalities of the floodplains. For instance, works affecting the river such as regulation of river channels or construction of hydropower plants have disrupted the hydrological connection between rivers and floodplains and affected the frequency, extent and duration of flood events (Ward et al., 1999). Also, agricultural activities have developed to such a degree that more than $90 \%$ of North American and European floodplains are

\footnotetext{
*Corresponding author: joau@dmu.dk
}

cultivated (Tockner and Stanford, 2002). Consequently, degradation of the rivers and use of fertilizers combined with subsidence have led to leaching of nitrogen $(\mathrm{N})$ and phosphorus $(\mathrm{P})$ and the subsequent eutrophication of aquatic recipients (Carpenter et al., 1998; Birgand et al., 2007; Moss, 2008).

To combat eutrophication, restoration of rivers and riparian areas such as floodplains and river valleys has become an important way of reducing nutrient loads to aquatic systems (Mitsch and Jørgensen, 2003; Hoffmann and Baattrup-Pedersen, 2007; Moss and Monstadt, 2008) and improving the environmental state of valuable rivers and floodplain ecosystems or habitats. During flood events, a substantial amount of sediment may be deposited in floodplains and the $\mathrm{N}$ and $\mathrm{P}$ associated with this deposited sediment are therefore trapped in the floodplain, thus reducing the nutrient load to the river. Although deposition on floodplains is generally not considered a main process of $\mathrm{N}$ removal, deposition of particulate $\mathrm{N}$ in floodplains during inundation is also of importance (Olde Venterick et al., 2006). Phosphorus is mainly transported in streams in particulate form and previous studies have shown that floodplains act as traps for sedimentbound P (Vought et al., 1994; Olde Venterick et al., 2006; Hoffmann et al., 2009). 
Nevertheless, there are still some uncertainties regarding the efficiency of floodplains as a restoration measure (e.g., Aldous et al., 2007; Craig et al., 2008) and especially about the fate of deposited nutrients after flood events (Noe and Hupp, 2009). Indeed, while several studies have documented $\mathrm{N}$ and $\mathrm{P}$ deposition in natural floodplains (Johnston, 1991; Brunet et al., 1994; Walling et al., 1999; Olde Venterick et al., 2006, Kronvang et al., 2007) or restored floodplains (Kronvang et al., 1998, 2009), retention of the sediment-associated nutrients after their deposition has been overlooked. Therefore, quantification of $\mathrm{N}$ and $\mathrm{P}$ leaching from deposited sediment is of interest for estimating the efficiency of floodplain restoration as a permanent nutrient sink.

The main objective of this study was to investigate the $\mathrm{N}$ and $\mathrm{P}$ retention capacity of freshly deposited floodplain sediment. We examined the $\mathrm{N}$ and $\mathrm{P}$ leaching from sediment collected from a restored floodplain along River Odense in a laboratory set-up mimicking spring field conditions regarding temperature and rainfall over a 2-month period. We hypothesized that the exposure of fresh sediment to rainfall events may lead to leaching of $\mathrm{N}$ and $\mathrm{P}$.

\section{Materials and methods}

\section{Study site}

The studied floodplain is situated $20 \mathrm{~km}$ south of the city of Odense $\left(55^{\circ} 13^{\prime} \mathrm{N}, 10^{\circ} 15^{\prime} \mathrm{W}\right.$; Fig. 1$)$ along the River Odense, a fifth-order stream with an average annual discharge of $6.5 \mathrm{~m}^{3} . \mathrm{s}^{-1}$ (Thodsen, 2007) and a slope of $0.127 \%$. The River Odense discharges into Odense Fjord, which suffers from eutrophication (Petersen et al., 2009). The catchment area of the River Odense encompasses ca. $1050 \mathrm{~km}^{2}$ of lowland. The land is mainly used for agriculture, $68 \%$, while urban areas occupy $16 \%$, woodland $10 \%$ and lakes and wetlands $6 \%$ (Fyns Amt, 2003). The catchment soil type is mostly clay, $51 \%$, and sandy loam, 49\% (Fyns Amt, 2003). Annual precipitation is around $740 \mathrm{~mm}$ and annual mean temperature is $8.2^{\circ} \mathrm{C}$ (Fyns Amt, 2003). During the first half of the 20th century, several stretches of the River Odense were straightened and channelized for agricultural purposes. But in autumn 2003 , as part of a restoration project aiming at mitigating the nutrient load and improving the conditions for the river and the fjord, the floodplain was converted from arable land in crop rotation to a permanently grazed meadow. A total of 78.4 ha of riparian areas were restored by remeandering the river that enabled the groundwater level to rise and hence created wetter conditions in the surrounding areas (Kronvang et al., 2009).

\section{Field methods}

Briefly, following Kronvang et al. (2009) sediment deposited on the floodplain during flood events was collected along a transect placed perpendicularly to the river channel (Fig. 1). A transect length extending from the river bank to the valley slope was chosen to cover the width of the floodplain. The sediment was trapped using duplicate large artificial grass mats (Astroturf ${ }^{\circledR}$ $30 \times 30 \mathrm{~cm}$, Textile Management Associates Inc., Dalton, GA, USA) that were placed at increasing distances along the transect $(8,16.5,23.8$ and $101 \mathrm{~m}$; Fig. 1). Artificial grass mats were installed on the floodplain on October 24, 2007 and were harvested on March 26, 2008. Flooding events on the floodplain were recorded based on continuous water stage monitoring at a downstream river station (Nr. Broby, $\left.55^{\circ} 15^{\prime} \mathrm{N}, 10^{\circ} 13^{\prime} \mathrm{W}\right)$. During the winter period of 2007-2008, the studied floodplain was flooded 68 days and the last flooding event ceased on March 25, 2008.

\section{Laboratory procedures}

After harvesting, the artificial mats with sediment were kept at $4{ }^{\circ} \mathrm{C}$ and in darkness until further processing. After 4-5 days, four artificial grass mats (one per sampling distance) were placed on a special-designed bottom tray lined with a $30 \mu \mathrm{m} \mathrm{Nytal}{ }^{\circledR}$ mesh. Despite that only four mats were used in this experiment, we expected significant differences in sediment characteristics because of sediment textural sorting during deposition. The samples were not replicated in the incubation, but the size of the mats $(30 \times 30 \mathrm{~cm})$ enabled us to obtain a large sample, especially when compared with smaller mats $(15 \times 15 \mathrm{~cm})$ that are often used in sedimentation studies (e.g., Kronvang et al., 2007, 2009). The mats were subjected to simulated rainfall for two months in a climatic chamber under conditions that reproduced spring temperature $\left(8^{\circ} \mathrm{C}\right.$ in the first month and $12^{\circ} \mathrm{C}$ in the second month) and precipitation (43 $\mathrm{mm}$ in the first month and $47 \mathrm{~mm}$ in the second month) in Denmark. To mimic the alternation of rainy and dry periods, the monthly rainfall amount was divided into nine rain events. The amount of rainwater for each event was weighed out in a beaker and then pumped at a speed of $1.5 \mathrm{~mm} \cdot \mathrm{h}^{-1}$. Thus, a rain event lasted between $c a$. 198 and $228 \mathrm{~min}$. The precipitation was applied as two rain events on two consecutive days before allowing the sediment to air dry for five days. The constant rate of $1.5 \mathrm{~mm} \cdot \mathrm{h}^{-1}$ simulated conditions of a light rain and is typical of Danish spring conditions (Vejen, 2005).

The rainfall simulator consisted of a $30 \mathrm{~cm}$ circular dosing head equipped with 180 needles. From a reservoir placed on a balance, artificial rainwater was applied to the artificial grass mats with deposited sediment using a peristaltic pump. The composition of the artificial rainwater was representative of Danish rainwater (Ellermann et al., 2007; Ellermann, personal communication) and had the following nutrient concentrations: ammonium-N $\left(\mathrm{NH}_{4}\right)=0.50 \mathrm{mg} . \mathrm{L}^{-1}$, nitrate- $\mathrm{N}=0.48 \mathrm{mg.L}^{-1}$, chloride $=5.76 \mathrm{mg} . \mathrm{L}^{-1}$, potassium $=1.34 \mathrm{mg} . \mathrm{L}^{-1}$, sodium $=$ $2.67 \mathrm{mg} . \mathrm{L}^{-1}$, calcium $=0.21 \mathrm{mg} . \mathrm{L}^{-1}$, magnesium $=0.069$ mg. $\mathrm{L}^{-1}$ and sulfate $=0.273 \mathrm{mg} . \mathrm{L}^{-1}$. The artificial rainwater that percolated through the sediment was caught in 


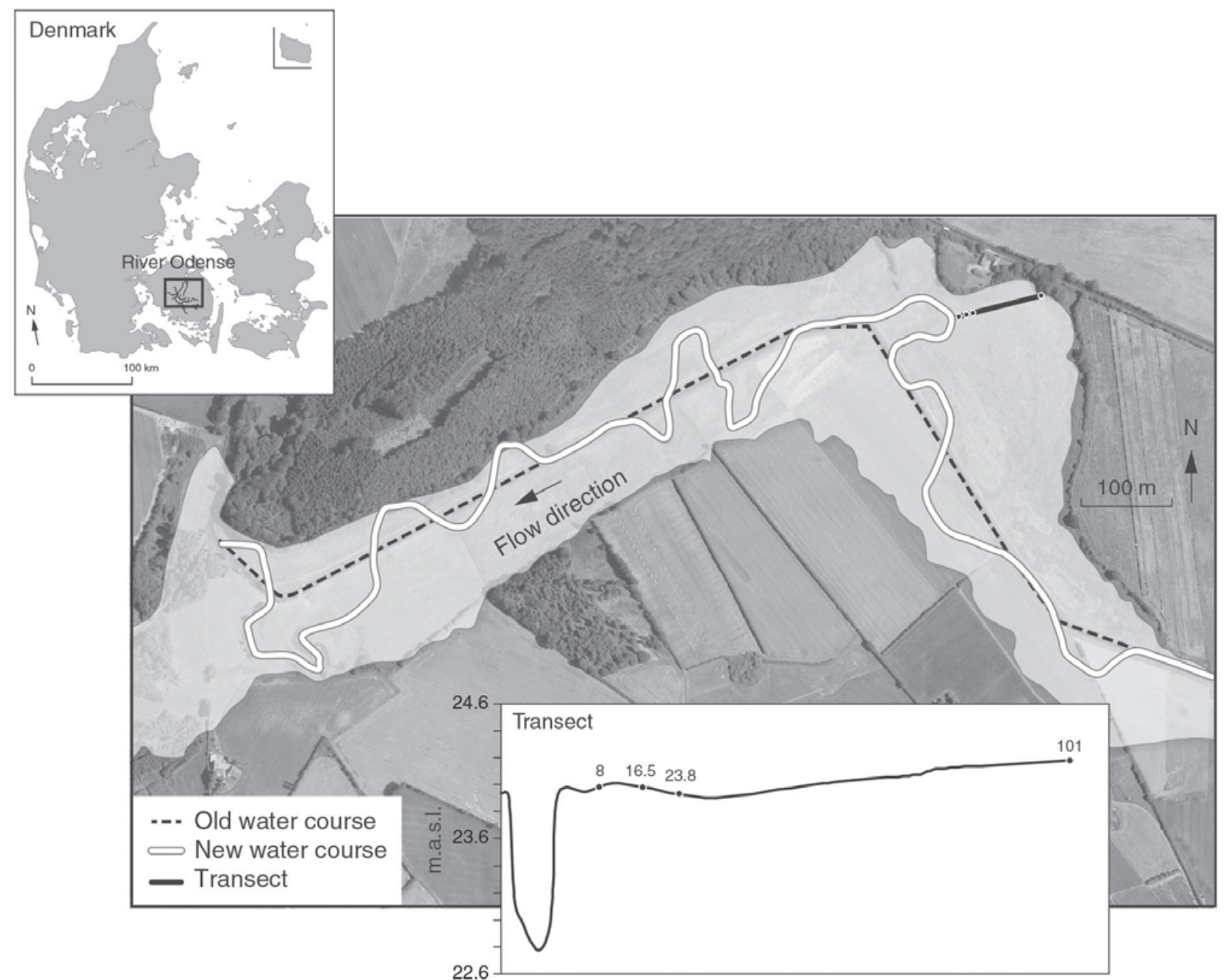

Fig. 1. Map of the restored floodplain and profile of the transect showing the location of the artificial grass mats used to collect sediment deposited during flood event.

the bottom tray, which was connected to a sampling bottle placed underneath the tray. The collected water was sampled 5-6 h after each rainfall event and $24 \mathrm{~h}$ after the second rainfall event of every rainy period (i.e., three samples per 2-day rain period). Exchange of nutrients between the sediment and the water phase was calculated as difference in nutrient concentration between the rainwater applied and the water collected after percolation through the sediment.

Water samples were immediately filtered through $0.45 \mu \mathrm{m}$ filters (Cameo 25GAS filter). Ammonium-N and nitrate-nitrite- $\mathrm{N}\left(\mathrm{NO}_{3}\right)$ in the water samples were analyzed according to the Danish/European standard (DS/EN ISO 13395, 1997; DS/EN ISO 11732, 2005) and measured spectrophotometrically at 660 and $520 \mathrm{~nm}$, respectively, on Lachat FIA QC-8000. Phosphate $\left(\mathrm{PO}_{4}\right)$ was determined using the molybdenum blue method according to the Danish/European DS/EN ISO 6878 standard (2004) and measured spectrophotometrically at $880 \mathrm{~nm}$ on Lachat FIA QC-8000 (Lachat, Milwaukee, WI, USA). Total dissolved phosphorus (TDP) was determined as $\mathrm{PO}_{4}$ following peroxydisulfate digestion in an autoclave (DS/EN ISO 6878, 2004). Dissolved organic phosphorus
(DOP) was determined as the difference between the concentration of TDP and $\mathrm{PO}_{4}$ in the water sample.

Non-incubated sediment deposited on parallel grass mats was used to determine the sedimentation rate and characteristics of the sediment. The amount of sediment deposited was determined by drying $48 \mathrm{~h}$ at $60^{\circ} \mathrm{C}$ and weighing the amount of dry sediment. Total phosphorus (TP) was determined as $\mathrm{PO}_{4}$ after combustion in a muffle furnace at $550{ }^{\circ} \mathrm{C}$ and boiling of the ash with $0.1 \mathrm{M} \mathrm{HCl}$ (Andersen, 1976). Phosphorus in the sediment that adsorbed onto oxidized species of iron and manganese, often denoted as "the iron-bound P-fraction", was determined after extraction with bicarbonate-dithionite (BD reagent) (Psenner et al., 1984; Paludan and Jensen, 1995). Iron ( $\mathrm{Fe}$ ) extracted by BD was analyzed by ICP (PerkinElmer Optima 2100, Waltham, MA, USA). This $\mathrm{Fe}$ is considered to represent ferric oxyhydroxides able to bind $\mathrm{P}$ (Psenner et al., 1984; Jensen and Thamdrup, 1993). Organic matter (OM) was determined as loss on ignition after $3 \mathrm{~h}$ of combustion in a muffle furnace at $550{ }^{\circ} \mathrm{C}$. Sediment samples were analyzed for total nitrogen (TN) and total organic carbon (C) using an automated $\mathrm{C}: \mathrm{N}$ analyzer (Roboprep- $\mathrm{G}+$ ) coupled to 
Table 1. Deposition of sediment, TN and TP along a transect in the River Odense floodplain. Sediment content in TP, TN and OM. $\mathrm{C}: \mathrm{N}$ is the carbon:nitrogen ratio in the sediment and $\mathrm{Fe}: \mathrm{PO}_{4}$ (by weight) is the iron:phosphate ratio in the iron-bound $\mathrm{P}$ fraction in the sediment. Different letters indicate significant differences $(P<0.05)$ between sediment located at different distances from the river bank. Results $\pm \mathrm{SE}$, number of replicates $=2$.

\begin{tabular}{|c|c|c|c|c|c|c|c|c|}
\hline $\begin{array}{l}\text { Distance } \\
\text { of sampling } \\
(\mathrm{m})\end{array}$ & 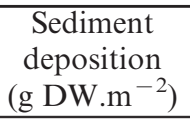 & $\begin{array}{c}\text { TP } \\
\text { deposition } \\
\left(\mathrm{g} \mathrm{DW}^{\left.-\mathrm{m}^{-2}\right)}\right.\end{array}$ & $\begin{array}{c}\text { TN } \\
\text { deposition } \\
\left(\mathrm{g} \mathrm{DW}^{\left.-\mathrm{m}^{-2}\right)}\right.\end{array}$ & TP $\left(\mu \mathrm{g} \cdot \mathrm{g}^{-1} \mathrm{DW}\right)$ & $\mathrm{TN}\left(\mu \mathrm{g} \cdot \mathrm{g}^{-1} \mathrm{DW}\right)$ & $\mathrm{OM}(\%)$ & $\mathrm{C}: \mathrm{N}$ & $\mathrm{Fe}: \mathrm{PO}_{4}$ \\
\hline 8 & 8969 & 19 & 41 & $2065 \pm 4^{\mathrm{a}}$ & $4576 \pm 12^{\mathrm{a}}$ & $21.2 \pm 3.8^{\mathrm{a}}$ & $13.7 \pm 0.2^{\mathrm{a}}$ & 11.2 \\
\hline 16.5 & 4555 & 14 & 35 & $2997 \pm 13^{\mathrm{a}, \mathrm{b}}$ & $7709 \pm 30^{\mathrm{b}}$ & $23.7 \pm 0.4^{\mathrm{a}}$ & $11.9 \pm 0.4^{\mathrm{b}}$ & 13.9 \\
\hline 23.8 & 2391 & 8 & 25 & $3351 \pm 25^{\mathrm{b}}$ & $10456 \pm 10^{\mathrm{c}}$ & $25.7 \pm 0.6^{\mathrm{a}}$ & $10.1 \pm 0.0^{\mathrm{c}}$ & 14.9 \\
\hline 101 & 587 & 3 & 15 & $4830 \pm 2^{c}$ & $24947 \pm 34^{\mathrm{d}}$ & $64.0 \pm 0.1^{\mathrm{b}}$ & $7.7 \pm 0.3^{\mathrm{d}}$ & 39.6 \\
\hline
\end{tabular}

a Europa Tracermass spectrometer (Europa Scientific, Crewe, Cheshire East, UK).

\section{Statistical analysis}

Sediment characteristics were analyzed by one way ANOVA and Tukey HSD post-hoc test was used for multiple comparisons. Linear regressions were used to fit the cumulated curve of nutrient exchange. When necessary the data were log transformed. The same transformation was applied to every curve of each data set to allow comparison of the slopes of the regressions following the procedure described in Zar (1999). Multiple comparisons among slopes were done using Tukey HSD post-hoc test. The significance level for all tests is $P<0.05$.

\section{Results}

The total amount of sediment deposited during the winter period 2007-2008 decreased with increasing distance to the river. At a distance of $8 \mathrm{~m}$ the deposition was $8969 \mathrm{~g} \mathrm{DW} . \mathrm{m}^{-2}$ and at $101 \mathrm{~m}$ it was only $587 \mathrm{~g} \mathrm{DW} . \mathrm{m}^{-2}$ (Table 1). The TP content in the sediment increased gradually with distance to the river, ranging from 2065 to $4830 \mu \mathrm{g} \mathrm{P.g}{ }^{-1}$ DW at 8 and $101 \mathrm{~m}$, respectively (Table 1). Total $\mathrm{N}$ in the sediment increased gradually from 4576 $\mu \mathrm{g} . \mathrm{g}^{-1} \mathrm{DW}$ at a distance of $8 \mathrm{~m}$ to $24947 \mu \mathrm{g} \cdot \mathrm{g}^{-1} \mathrm{DW}$ at $101 \mathrm{~m}$ (Table 1). Both TN and TP deposition reached maximum values $8 \mathrm{~m}$ from the channel and minimum values $101 \mathrm{~m}$ from the river (Table 1). The OM content increased slightly from 21 to $26 \%$ between 8 and $23.8 \mathrm{~m}$ from the channel, but then increased significantly to $64 \%$ in the sediment deposited at $101 \mathrm{~m}$ (Table 1). The C:N ratio decreased gradually from 13.7 to 7.7 at 8 and $101 \mathrm{~m}$, respectively (Table 1). The $\mathrm{Fe}: \mathrm{PO}_{4}$ ratio (by weight) in the $\mathrm{BD}$ extracts rose gradually from 11.2 to 39.6 and from 8 to $101 \mathrm{~m}$, indicating a higher P-binding capacity with increasing distance to the river (Table 1). One-way ANOVA revealed significant differences among the sediment samples as to the content of TP $(P<0.01)$, TN $(P<0.001), \mathrm{OM}(P<0.001)$ and $\mathrm{C}: \mathrm{N}(P<0.001)$. Results of multiple comparisons are presented in Table 1.

Each of the four mats received $90 \mathrm{~mm}$ of rainwater and this corresponded to an input of $86.5 \mathrm{mg} \mathrm{N} . \mathrm{m}^{-2}$ (i.e., $51 \%$ as $\mathrm{NO}_{3}$ and $49 \%$ as $\mathrm{NH}_{4}$ ). Transformation of the $\mathrm{N}$ content in the rainwater to an input per gram of deposited sediment showed than $\mathrm{N}$ rainfall deposition ranged from 10 to $147 \mu \mathrm{g} \mathrm{N} \cdot \mathrm{g}^{-1} \mathrm{DW}$ at 8 and $101 \mathrm{~m}$, respectively.

A comparison of the $\mathrm{NH}_{4}$ concentration in the rainwater and the water having percolated through the sediment revealed an uptake of $\mathrm{NH}_{4}$ in the sediment (Fig. 2A). After 60 days of experiment, the uptake of $\mathrm{NH}_{4}$ in the mat located at $8 \mathrm{~m}$ was $3.34 \mu \mathrm{g} \cdot \mathrm{g}^{-1} \mathrm{DW}$, while the uptake of $\mathrm{NH}_{4}$ in the mat located at $101 \mathrm{~m}$ was $47.4 \mu \mathrm{g} . \mathrm{g}^{-1}$ DW (Table 2).

Nitrate was leached from the sediment on the mats which was evidenced by the fact that the $\mathrm{NO}_{3}$ concentration in percolating water was higher than $\mathrm{NO}_{3}$ concentration in rainwater (Fig. 2B). The $\mathrm{NO}_{3}$-release from the sediment ranged from 2.72 to $1600 \mu \mathrm{g} . \mathrm{g}^{-1} \mathrm{DW}$ at 8 and $101 \mathrm{~m}$, respectively (Table 2). The total release of dissolved inorganic $\mathrm{N}$ species (only $\mathrm{NO}_{3}$ in this case) after 60 days of experiment varied between 0.06 and $6.42 \%$ of TN content in the sediment.

During the 60 days of the experiment, a release of $\mathrm{PO}_{4}$ from the sediment to the water phase occurred (Fig. 2C). The amount of $\mathrm{PO}_{4}$ released from the sediment after 60 days varied between 0.29 and $1.17 \mu \mathrm{g} \mathrm{P.g}{ }^{-1} \mathrm{DW}$ at a distance of 8 and $23.8 \mathrm{~m}$ from the river channel, respectively (Table 1$)$.

Release of DOP from the sediment increased with increasing distance to the river channel (Fig. 2D). At the end of the experiment, the amount of DOP released to the water ranged between 0.16 and $2.03 \mu \mathrm{g} \mathrm{P.g}{ }^{-1} \mathrm{DW}$ at 8 and $101 \mathrm{~m}$, respectively (Table 1). The release of TDP (i.e., $\left.\mathrm{PO}_{4}+\mathrm{DOP}\right)$ during the experiment ranged between 0.021 and $0.065 \%$ of the TP content in the sediment deposited at a distance of 8 and $101 \mathrm{~m}$ from the river channel, respectively.

The comparison of $\mathrm{NH}_{4}$ uptake rates showed significant differences $\left(F_{3,88}=1059, P<0.001\right)$ and the highest uptake rate was found in the sediment deposited at $101 \mathrm{~m}$ (Fig. 2A). Nitrate release rates demonstrated significant differences $\left(F_{3,88}=46 ; P<0.001\right)$, but the release rate in the sediment found at $101 \mathrm{~m}$ did not differ significantly from those in the other sediments (Fig. 2B). Phosphate release rates were significantly different $\left(F_{3,88}=394\right.$, $P<0.001)$ and the highest rate was found at $23.8 \mathrm{~m}$ (Fig. 2C). DOP release rates exhibited significant 
Table 2. Exchange of ammonium $\left(\mathrm{NH}_{4}\right)$, nitrate $\left(\mathrm{NO}_{3}\right)$, phosphate $\left(\mathrm{PO}_{4}\right)$ and DOP between the sediment and the water phase after a 2-months simulation period of spring temperatures and rainfall. Negative values indicate uptake by the sediment.

\begin{tabular}{lcccc}
\hline $\begin{array}{l}\text { Distance of } \\
\text { sampling }(\mathrm{m})\end{array}$ & $\begin{array}{c}\mathrm{NH}_{4} \\
\left(\mu \mathrm{g} \mathrm{N}^{-1} \mathrm{DW}\right)\end{array}$ & $\begin{array}{c}\mathrm{NO}_{3} \\
\left(\mu \mathrm{g} \mathrm{N.g}{ }^{-1} \mathrm{DW}\right)\end{array}$ & $\begin{array}{c}\mathrm{PO}_{4} \\
\left(\mu \mathrm{g} \mathrm{P.g}^{-1} \mathrm{DW}\right)\end{array}$ & $\begin{array}{c}\mathrm{DOP} \\
\left(\mu \mathrm{g} \mathrm{P} . \mathrm{g}^{-1} \mathrm{DW}\right)\end{array}$ \\
\hline 8 & -3.34 & 2.72 & 0.29 & 0.16 \\
16.5 & -6.38 & 8.45 & 0.79 & 0.25 \\
23.8 & -14.1 & 30.6 & 1.17 & 0.62 \\
101 & -47.4 & 1600 & 1.12 & 2.03 \\
\hline
\end{tabular}
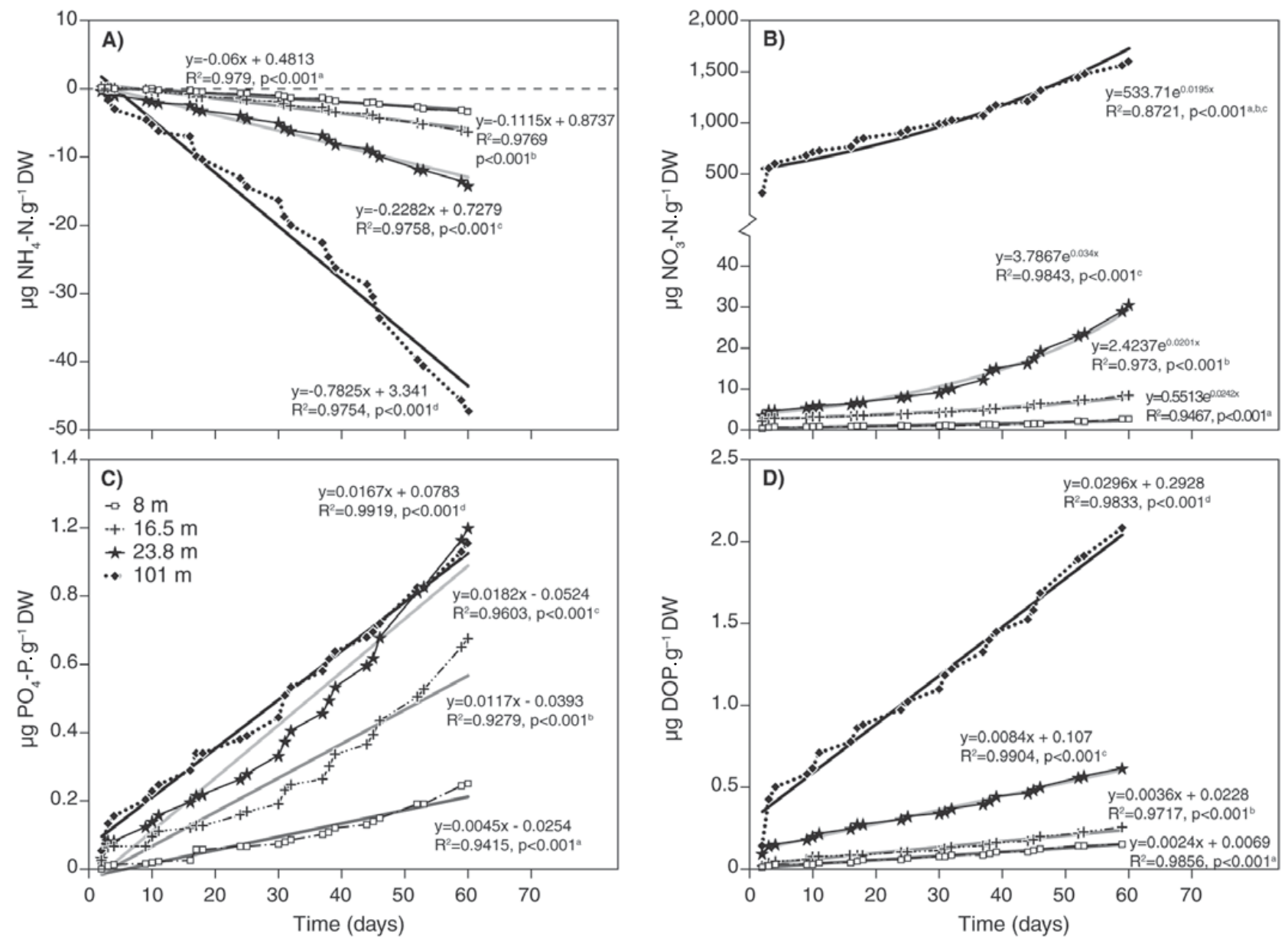

Fig. 2. Cumulated concentration of $(\mathrm{A})$ ammonium $\left(\mathrm{NH}_{4}\right)$, (B) nitrite + nitrate $\left(\mathrm{NO}_{3}\right),(\mathrm{C})$ phosphate $(\mathrm{PO})$ and $(\mathrm{D})$ DOP in the water collected after percolation through the sediment deposited in the River Odense floodplain at different sampling distances. Different letters indicate significant differences $(P<0.05)$ between the slopes of the curves.

differences $\left(F_{3,84}=758, P<0.001\right)$ and increased with increasing distance to the channel (Fig. 2D).

\section{Discussion}

Several studies have demonstrated the importance of floodplains as a trap for sediment and sediment-associated nutrients (Walling et al., 1999; Olde Venterick et al., 2006; Kronvang et al., 2007; Noe and Hupp, 2009). In the present study, the sedimentation rates found for the restored floodplain (Table 1) are comparable with the values measured in 21 floodplains in the UK (400-
12200 g.m ${ }^{-2} \cdot \mathrm{yr}^{-1}$; Walling et al., 1999) and also with sedimentation rates at 17 sites located along rivers in the Chesapeake watershed in the USA (303-4600 g.m ${ }^{-2} \cdot \mathrm{yr}^{-1}$; Noe and Hupp, 2009). A study conducted by Kronvang et al. (2007) in four Danish floodplains revealed deposition rates between 3000 and 6570 g.m ${ }^{-2} \cdot \mathrm{yr}^{-1}$. However, a much higher deposition rate of $23000 \mathrm{~g} \cdot \mathrm{m}^{-2} \cdot \mathrm{yr}^{-1}$ was found in a floodplain located along the River Danube in Austria (Tockner et al., 1999).

Total $\mathrm{N}$ deposition measured in this study (Table 1) is of the same order of magnitude as the rates found in five Dutch floodplains (4.2-56.8 g N DW.m ${ }^{-2} . \mathrm{yr}^{-1}$; Olde Venterick et al., 2006) and in North American coastal 
floodplains (2.2-12 g N DW.m ${ }^{-2} \cdot \mathrm{yr}^{-1}$; Noe and Hupp, 2009). Total $\mathrm{P}$ deposition (Table 1) was higher compared to values of $0.2-3.5 \mathrm{~g} \mathrm{P}$ DW.m ${ }^{-2} \cdot \mathrm{yr}^{-1}$ found by Noe and Hupp (2009) and in four Danish floodplains (1.27.3 g P DW.m ${ }^{-2}$.yr ${ }^{-1}$; Kronvang et al., 2007).

The sediment released $\mathrm{NO}_{3}$, but took up $\mathrm{NH}_{4}$. However, the total inorganic $\mathrm{N}$ release from the sediment did not exceed $6.42 \%$ of the TN content in the sediment. A possible explanation for this might be that the $\mathrm{NH}_{4}$ originating from the rainwater was adsorbed on minerals, taken up by bacteria or transformed to $\mathrm{NO}_{3}$ in the sediment. According to Drury and Beauchamp (1991) and Trehan (1996), adsorption of $\mathrm{NH}_{4}$ on clay minerals is prompt $(<30 \mathrm{~min})$, but generally accounts for less than $10 \%$ of the $\mathrm{NH}_{4}$ applied to soil. Brookes et al. (1985) found that $10-34 \%$ of $\mathrm{NH}_{4}$ in soils is immobilized by micro-organisms, and this indicates that micro-organisms may have contributed to the uptake of $\mathrm{NH}_{4}$. In our study, some of these micro-organisms may have been nitrifiers that transform $\mathrm{NH}_{4}$ to $\mathrm{NO}_{3}$. Therefore, it seems likely that part of $\mathrm{NO}_{3}$ leached by the sediment originated from rainwater $\mathrm{NH}_{4}$. Assuming that the whole $\mathrm{NH}_{4}$ uptake is nitrified to $\mathrm{NO}_{3}$ and subsequently released, it signifies that, since the $\mathrm{NO}_{3}$ release from the sediment deposited from 16.5 to $101 \mathrm{~m}$ is larger than the $\mathrm{NH}_{4}$ uptake, part of the $\mathrm{NO}_{3}$ does not come from the rainwater but originates from the mineralization of OM.

The sediment showed significant differences regarding $\mathrm{NH}_{4}$ uptake rates, which increased with increasing distance to the river. Furthermore, the rates of $\mathrm{NO}_{3}$ release also revealed marked differences even though the release rate of the sediment collected at $101 \mathrm{~m}$ did not differ significantly from those recorded in the other sediments. These differences might be explained by contrasting sediment characteristics (i.e., TN and OM content and $\mathrm{C}: \mathrm{N}$ ratio) due to textural sorting during deposition on the floodplain. During overbank flooding, coarse particles are generally deposited closer to the river banks, while fine particles richer in nutrients may deposit further away (Kronvang et al., 2007). Additionally, bacterial activity is favored by low C:N ratios (Reddy and Delaune, 2008) and this may explain the higher $\mathrm{NH}_{4}$ uptake (by increased microbial uptake or nitrification) with increasing distance to the river. Increasing release of $\mathrm{NO}_{3}$ with increasing distance to the river might be explained both by higher mineralization and higher nitrification in relation with higher TN and OM contents in the sediment as well as by higher bacterial activity due to the lower $\mathrm{C}: \mathrm{N}$ content.

The release of $\mathrm{PO}_{4}$ and DOP was very low and did not account for more than $0.065 \%$ of the total $\mathrm{P}$ content in the sediment. The Fe: $\mathrm{PO}_{4}$ ratio in the iron-bound $\mathrm{P}$ fraction, which is often used as an indicator of the potential $\mathrm{PO}_{4}$ release (Jensen and Thamdrup, 1993), was relatively low (i.e., $<15$, by weight) in the sediment collected between 8 and $23.8 \mathrm{~m}$, but high (40) in the sediment collected at $101 \mathrm{~m}$. Jensen et al. (1992) found that an Fe:P ratio of at least 15 was needed to prevent $\mathrm{PO}_{4}$ release from aerobic freshwater sediment. Surprisingly, despite that the deposits had a high $\mathrm{P}$ content and some of them low Fe: $\mathrm{PO}_{4}$ the release of $\mathrm{PO}_{4}$ was negligible. This might be due to the fact that freshly deposited sediment might contain a high amount of amorphous iron oxyhydroxides which can offer more binding sites for $\mathrm{PO}_{4}$ than crystallized iron oxyhydroxides (Loeb et al., 2008) even at low Fe:PO $\mathrm{PO}_{4}$

DOP release rates differed significantly among the sediments, with increasing rates in the sediment deposited further away from the river. An explanation for this may be increasing contents of TP and OM in the sediment (i.e., a larger $\mathrm{P}$ pool) with increasing distance to the river. Also, increasing sediment mineralization rates with increasing distance to the river may have increased $\mathrm{P}$ mobilization and release, and this is consistent with the release rates of $\mathrm{NO}_{3}$.

Under natural conditions, part of the $\mathrm{N}$ and $\mathrm{P}$ leached from the sediment may be used for plant uptake. In fact, the amount of $\mathrm{P}$ released during the experiment may supply the amount of $\mathrm{P}$ needed for plant growth in April and May. In our study, the highest release of TP amounted to $0.55 \mathrm{~g}$ TP. $\mathrm{m}^{-2}$, and in Denmark meadow plants need between 0.2 and $0.3 \mathrm{~g} \mathrm{TP.m}{ }^{-2}$ to cover aboveground production in April and May (Hoffmann et al., 2006). The highest $\mathrm{N}$ release in the experiment was $0.94 \mathrm{~g} \mathrm{~N} . \mathrm{m}^{-2}$, and plant $\mathrm{N}$ uptake by Danish meadow plants varies from 2.3 to $4.3 \mathrm{~g} \mathrm{~N} . \mathrm{m}^{-2}$ (Hoffmann et al., 2006).

The rainfall simulated was of light intensity and it might be assumed that under natural conditions intense rainfall events may contribute to nutrient leaching because of physical disruption of the sediment particles. Also, the soil moisture content in the incubated sediment differed from that under field conditions. Furthermore, this experiment did not test the effect of intra-day variation in temperature, which may have affected biological processes such as mineralization (Stanford et al., 1973) or nitrification (Frederick, 1956).

Despite that our results show positive $\mathrm{N}$ and $\mathrm{P}$ retention values in floodplain sediment, more investigations are needed to follow the nutrient retention over longer time periods, especially when the sediment is re-flooded and becomes anaerobic, which potentially may lead to substantial $\mathrm{P}$ release of $\mathrm{Fe}$ bound $\mathrm{P}$. As in the case of nitrogen, release of organic $\mathrm{N}$ was not measured in this study but might have contributed significantly to the $\mathrm{N}$ release. Furthermore, the low $\mathrm{N}$ release might also be explained by the fact that the sediment was immersed in the river water before its deposition, enabling release of soluble N. Even though this experiment was performed under aerobic conditions, $\mathrm{NO}_{3}$ removal by denitrification may have occurred at some small anaerobic spots in the sediment, thereby lowering the leaching of $\mathrm{NO}_{3}$.

Overall, our findings have important implications for estimating the efficiency of river and floodplain restoration projects to mitigate the nutrient load. Our study demonstrated that a substantial amount of sediment and associated $\mathrm{N}$ and $\mathrm{P}$ may be deposited on restored floodplains. Furthermore, despite a high nutrient content, the release of $\mathrm{N}$ and $\mathrm{P}$ from sediment exposed to spring rainfall amounts and spring temperatures was negligible, and part of the release might also be used to sustain plant growth. 
Consequently, our results support the idea that floodplain and river restoration is a relevant tool for mitigating the nutrient load to aquatic freshwater ecosystems. This is of importance in countries where there is a need to preserve or improve water resources, especially in Europe where the implementation of the Water Framework Directive (European Parliament and of the Council, 2000) requires that all water bodies have achieved good environmental status by 2015 . Our results confirm the relevance of applying restoration measures in Denmark where an objective of restoring 16000 ha of wetland and riparian areas has been established (Hoffmann and Baattrup-Pedersen, 2007).

\section{Conclusion}

The purpose of our study was to test nutrient retention in fresh sediment collected in a restored floodplain and placed in an experimental setup simulating spring rainfall and temperatures. Our findings show that restored floodplains act as efficient traps for sediment and sedimentassociated nutrients and that the release of $\mathrm{P}$ and inorganic $\mathrm{N}$ is very low despite a high content of nutrients in the sediment. The results of our study support the relevance of applying restoration of river floodplains to mitigate the nutrient load to aquatic recipients such as lake and fjords. Further investigations are needed to monitor the retention over a longer time period, in particular, when the sediment is rewetted.

Acknowledgements. The authors are grateful for financial support by two research projects: BUFFALO-P and MONITECH. The BUFFALO-P project is supported by the Danish Ministry of Food, Agriculture and Fishery under the program "Animal Husbandry, the Neighbours and the Environment" and the participating institutes. The MONITECH project is supported by the Danish Council for Strategic Research. Henning S. Jensen received additional support from the Danish Council for Independent Research - Natural Sciences (Grant no. 09071369) and from VKR Centre for Lake Restoration (CLEAR). We gratefully acknowledge the assistance from the technicians at NERI and SDU, A.M. Poulsen for manuscript editing and S.E. Larsen for help with the statistics. We also thank two anonymous reviewers and the associated editor for their valuable comments.

\section{References}

Aldous A.R., Craft C.B., Stevens C.J., Barry M.J. and Bach L.B., 2007. Soil phosphorus release from a restoration wetland, Upper Klamath Lake, Oregon. Wetlands, 27, 1025-1035.

Andersen J.M., 1976. Ignition method for determination of total phosphorus in lake sediments. Water Res., 10, 329-331.

Birgand F., Skaggs R.W., Chescheir G.M. and Gilliam J.W., 2007. Nitrogen removal in streams of agricultural catchments - A literature review. CRC C. R. Rev. Environ. Sci. Technol., 37, 381-487.
Brookes P.C., Kragt J.F., Powlson D.S. and Jenkinson D.S., 1985. Chloroform fumigation and the release of soil-nitrogen - the effects of fumigation time and temperature. Soil Biol. Biochem., 17, 831-835.

Brunet R.C., Pinay G., Gazelle F. and Roques L., 1994. Role of the floodplain and riparian zone in suspended matter and nitrogen-retention in the Adour River, south-west France. Regul. River., 9, 55-63.

Carpenter S.R., Caraco N.F., Correll D.L., Howarth R.W., Sharpley A.N. and Smith V.H., 1998. Nonpoint pollution of surface waters with phosphorus and nitrogen. Ecol. Appl., $8,559-568$.

Craig L.S., Palmer M.A., Richardson D.C., Filoso S., Bernhardt E.S., Bledsoe B.P., Doyle M.W., Groffman P.M., Hassett B.A., Kaushal S.S., Mayer P.M., Smith S.M. and Wilcock P.R., 2008. Stream restoration strategies for reducing river nitrogen loads. Front. Ecol. Environ., 6, 529-538.

Drury C.F. and Beauchamp E.G., 1991. Ammonium fixation, release, nitrification, and immobilization in high- and lowfixing soils. Soil Sci. Soc. Am. J., 55, 125-129.

DS/EN ISO 13395, 1997. Determination of nitrite nitrogen and nitrate nitrogen and the sum of both by flow analysis (CFA and FIA) and spectrometric detection.

DS/EN ISO 6878, 2004. Water quality - Determination of phosphorus - Ammonium molybdate spectrometric method.

DS/EN ISO 11732, 2005. Determination of ammonium nitrogen - Method by flow analysis (CFA and FIA) and spectrometric detection.

Ellermann T., Andersen H.V., Bossi R., Christensen J., Frohn L.M., Geels C., Kemp K., Løfstrøm P., Mogensen B.B. and Monies C., 2007. Atmosfærisk deposition 2006, NOVANA, Aarhus Universitet, Danmarks Miljøundersøgelser, Rapport fra DMU 645, 62 p. (in Danish).

European Parliament and of the Council, 2000. Establishing a framework for the Community action in the field of water policy, Directive 2000/60/EC.

Frederick L.R., 1956. The formation of nitrate from ammonium nitrogen in soils: 1. Effect of temperature. Soil Sci. Soc. Am. Proc., 20, 496-500.

Fyns Amt., 2003. Odense pilot river basin, Provisional Article 5 Report pursuant to the Water Framework Directive, Fyns Amt, Fyn County, 132 p.

Hoffmann C.C. and Baattrup-Pedersen A., 2007. Re-establishing freshwater wetlands in Denmark. Ecol. Eng., 30, 157-166.

Hoffmann C.C., Berg P., Dahl M., Larsen S.E., Andersen H.E. and Andersen B., 2006. Groundwater flow and transport of nutrients through a riparian meadow - Field data and modelling. J. Hydrol., 331, 315-335.

Hoffmann C.C., Kjaergaard C., Uusi-Kämppä J., Hansen H.C.B. and Kronvang B., 2009. Phosphorus retention in riparian buffers: review of their efficiency. J. Environ. Qual., 38, 1942-1955.

Jensen H.S. and Thamdrup B., 1993. Iron-bound phosphorus in marine sediments as measured by bicarbonate-dithionite extraction. Hydrobiologia, 253, 47-59.

Jensen H.S., Kristensen P., Jeppesen E. and Skytthe A., 1992. Iron-phosphorus ratio in surface sediment as an indicator of phosphate release from aerobic sediments in shallow lakes. Hydrobiologia, 235, 731-743.

Johnston C.A., 1991. Sediment and nutrient retention by freshwater wetlands - effects on surface-water quality. Crit. Rev. Environ. Contr., 21, 491-565. 
Junk J., Bayley P.B. and Sparks R.E., 1989. The flood pulse concept and in river-floodplain systems. Proceedings of the International Large River Symposium. Can. Spec. Publ. Aquat. Sci., 106, 110-127.

Kronvang B., Svendsen L.M., Brookes A., Fisher K., Moller B., Ottosen O., Newson M. and Sear D., 1998. Restoration of the rivers Brede, Cole and Skerne: a joint Danish and British EU-LIFE demonstration project, III - Channel morphology, hydrodynamics and transport of sediment and nutrients. Aquat. Conserv., 8, 209-222.

Kronvang B., Andersen I.K., Hoffmann C.C., Pedersen M.L., Ovesen N.B. and Andersen H.E., 2007. Water exchange and deposition of sediment and phosphorus during inundation of natural and restored lowland floodplains. Water Air Soil Pollut., 181, 115-121.

Kronvang B., Hoffmann C.C., Dröge R. and Andersen H.E., 2009. Sediment deposition and net phosphorus retention in a hydraulically restored lowland river floodplain in Denmark: combining field and laboratory experiments. Mar. Freshw. Res., 60, 638-646.

Loeb R., Lamers L.P.M. and Roelofs J.G.M., 2008. Prediction of phosphorus mobilisation in inundated floodplain soils. Environ. Pollut., 156, 325-331.

Mitsch W.J. and Jørgensen S.V., 2003. Ecological engineering and ecosystem restoration, 2nd edn., John Wiley and Sons, New York, $472 \mathrm{p}$.

Moss B., 2008. Water pollution by agriculture. Philos. Trans. R. Soc. B, 363, 659-666.

Moss T. and Monstadt J., 2008. Restoring Floodplains in Europe: Policy Contexts and Project Experiences, IWA Publishing, London, $355 \mathrm{p}$.

Naiman R.J. and Decamps H., 1997. The ecology of interfaces: Riparian zones. Annu. Rev. Ecol. Evol. Syst., 28, 621-658.

Noe G.B. and Hupp C.R., 2009. Retention of riverine sediment and nutrient loads by coastal plain floodplains. Ecosystems, $12,728-746$.

Olde Venterink H., Vermaat J.E., Pronk M., Wiegman F., van der Lee G.E.M., van den Hoorn M.W., Higler L.W.G.B. and Verhoeven J.T.A., 2006. Importance of sediment deposition and denitrification for nutrient retention in floodplain wetlands. Appl. Veg. Sci., 9, 163-174.

Paludan C. and Jensen H.S., 1995. Sequential extraction of phosphorus in freshwater wetland and lake sediment: significance of humic acids. Wetlands, 15, 365-373.

Petersen J.D., Rask N., Madsen H.B., Jorgensen O.T., Petersen S.E., Nielsen S.V.K., Pedersen C.B. and Jensen M.H., 2009. Odense Pilot River Basin: implementation of the EU Water Framework Directive in a shallow eutrophic estuary (Odense Fjord, Denmark) and its upstream catchment. Hydrobiologia, 629, 71-89.
Pinay G., Black V.J., Planty-Tabacchi A.M., Gumiero B. and Decamps H., 2000. Geomorphic control of denitrification in large river floodplain soils. Biogeochemistry, 50, 163-182.

Pinay G., Gumiero B., Tabacchi E., Gimenez O., TabacchiPlanty A.M., Hefting M.M., Burt T.P., Black V.A., Nilsson C., Iordache V., Bureau F., Vought L., Petts G.E. and Decamps H., 2007. Patterns of denitrification rates in European alluvial soils under various hydrological regimes. Freshw. Biol., 52, 252-266.

Psenner R., Pucko R. and Sager M., 1984. Die fraktionierung organischer und anorganischer Phosphorverbindungen von Sedimenten. Archiv. Hydrobiol., 70, 111-155 (in German).

Reddy K.R. and DeLaune R.D., 2008. Biogeochemistry of Wetlands: Science and Applications, CRC Press, Boca Raton, FL, 774 p.

Stanford G., Frere M.H. and Schwaninger D.H., 1973. Temperature coefficient of soil nitrogen mineralization. Soil Sci., 115, 321-323.

Thodsen H., 2007. The influence of climate change on stream flow in Danish rivers. J. Hydrol., 333, 226-238.

Tockner K., Pennetzdorfer D., Reiner N., Schiemer F. and Ward J.V., 1999. Hydrological connectivity, and the exchange of organic matter and nutrients in a dynamic riverfloodplain system (Danube, Austria). Freshw. Biol., 41, 521535.

Tockner K., Malard F. and Ward J.V., 2000. An extension of the flood pulse concept. Hydrol. Process., 14, 2861-2883.

Tockner K. and Stanford J.A., 2002. Riverine flood plains: present state and future trends. Environ. Conserv., 29, 308-330.

Trehan S.P., 1996. Immobilisation of $\left(\mathrm{NH}_{4}^{+}\right)-\mathrm{N}-15$ in three soils by chemical and biological processes. Soil Biol. Biochem., 28, $1021-1027$

Vejen F., 2005. Pilotprojekt: Beregning af dynamisk korrektion af nedbør på Samsø, 1989-2003, Danish Meteorological Institute, Copenhagen, Denmark, 51 p. (in Danish).

Vought L.B.M., Dahl J., Pedersen C.L. and Lacoursiere J.O., 1994. Nutrient retention in Riparian ecotones. Ambio, 23, 342-348.

Walling D.E., Owens P.N. and Leeks G.J.L., 1999. Rates of contemporary overbank sedimentation and sediment storage on the floodplains of the main channel systems of the Yorkshire Ouse and River Tweed, UK. Hydrol. Process., 13, 993-1009.

Ward J.V., Tockner K. and Schiemer F., 1999. Biodiversity of floodplain river ecosystems: Ecotones and connectivity. Regul. River, 15, 125-139.

Zar J.H., 1996. Comparing simple linear regression equations. In: Biostatistical Analysis, 3rd edn., Prentice Hall, Englewood Cliffs, NJ, 353-359. 